\title{
ADMINISTRATIVE LIABILITY FOR VIOLATION OF LEGISLATION IN THE SPHERE OF INTELLECTUAL PROPERTY
}

\section{Todoshak O. V.}

\section{INTRODUCTION}

The objective need to overcome infringements of intellectual property rights is explained, first of all, by the need to ensure the legal rights and interests of the subjects of these rights, as well as by creating conditions for compliance with the law on fair competition in business activity and the promotion of intellectual creative work. After all, in order for intellectual property to really play a significant role in the life of society and to ensure its development, a reliable system of its legal protection, including administrative and legal ones, and effective protection are required. The problem of administrative responsibility for infringement of intellectual property rights in modern conditions requires a deeper, more comprehensive, comprehensive analysis in order to identify its peculiarities. That is why there is an urgent need to apply both legislative and enforcement measures to create a coherent and effective system of protection and protection of intellectual property, an important place for administrative coercion and one of its types administrative responsibility for infringement of intellectual property legislation.

Administrative responsibility - is a complex and multifaceted phenomenon that covers administrative and legal norms, administrative legal relations, norms containing administrative sanctions, offenses with their statistical elements (object, objective party, subject and subjective) party), the activities of law enforcement agencies and their officials, etc.

The concept of "administrative responsibility" should integrate the following elements: it is a type of public relations, a reaction to the offense, and the application of appropriate sanctions, and an obligation to be constrained by the application of sanctions, and to reveal a compulsory method of government. In one definition, it is impossible to cover all the elements and features that characterize administrative responsibility.

The concept of administrative responsibility should synthesize two main definitions: the first characterizes administrative responsibility as an objective category, which expresses the state's response to an administrative offense, and the second - as a subjective-personal category, which characterizes it as a set of rights of the person being punished. 
Administrative responsibility should be understood to mean all measures of administrative and legal influence applicable to a person who has committed an administrative offense. These measures are implemented in legal relations that arise and objectively exist from the moment of committing an administrative offense - administrative-procedural law enforcement relations, which last for a certain period of time and cover all the main stages of proceedings in cases of administrative offenses, and their main subjects are the competent authority, vested with the power of jurisdiction, and the offender ${ }^{1}$.

\section{General principles of administrative responsibility for infringement of the legislation in the field of intellectual property}

The successful solution of the problem of administrative and legal protection of intellectual property rights depends on the preservation and multiplication of the intellectual capital of the state, the growth of its international authority, the degree of development of its civilization, and in the end, the level of democracy of society. That is why the field of intellectual property causes increased interest on the part of consumers of the results of intellectual creative activity, entrepreneurs, businessmen, different levels of executives, etc.

One of the types of legal responsibility is administrative liability, which is why when disclosing the concept and nature of administrative responsibility, it is necessary to take into account the general features and features of legal liability. However, administrative responsibility as a species phenomenon is inherent in certain features related to the basis of its occurrence, the nature of the measures of its impact and the procedure for its application. Administrative responsibility can be considered as the duty of the person who has committed an offense, stipulated by the norm of administrative law, to bear the burdensome consequences of personal, property and other nature ${ }^{2}$.

Thus, based on the general definition of legal responsibility, administrative responsibility for infringement of intellectual property law, in general, is the implementation of sanctions provided for by law for the administration of an administrative offense in the field of intellectual property.

The main features of administrative responsibility are that it: is a means of safeguarding the state order; normatively defined and consists in the application (implementation) of sanctions of legal norms; is the result of a

\footnotetext{
${ }^{1}$ Миколенко О.І., Стукаленко В.А., Стукаленко О.В. Адміністративна відповідальність посадових осіб за порушення виборчого законодавства : навч. посіб. Кіровоград : ПолімедСервіс, 2014. $170 \mathrm{c}$.

2 Олійник В.І. Адміністративна відповідальність за правопорушення в галузі рослинного світу України : монографія. Харків : НікаНова, 2015. 221 с.
} 
guilty anti-social act; is accompanied by state and public condemnation of the offender and his act; is connected with coercion, with negative consequences for the offender (moral or material nature), which he must suffer, and is also implemented in appropriate procedural forms.

Thus, administrative liability for infringement of intellectual property law includes, on the one hand, all the essential features of legal liability, in particular:

- it is a state-legal compulsion (compliance with the general rules of imposition of administrative penalties for administrative offenses during their application are manifested in the strict observance of the principles of the rule of law, legality, individualization of responsibility, etc.);

- the administrative responsibility for violation of the legislation in the field of intellectual property is normatively expressed and manifested in the application and implementation of sanctions of legal norms (the measures of administrative liability contain the final legal assessment of the offense committed by the subject of the offense, which is specified in the decision of the court in the application of the court ;

- this responsibility has a clear basis - an offense;

- it is imposed in a strictly established procedural order (in case of violation of property and non-property rights of the subjects of intellectual property rights to their respective objects of intellectual property, the court applies legal rules that determine the scope, limits, grounds of administrative responsibility, content and procedural forms of implementation of specific administrative penalties);

- it involves the aggravating consequences of property, moral, personal and other nature for the offender (administrative liability causes adverse effects on the offenders of intellectual property rights by imposing a fine and confiscation, deprivation or restriction of his rights).

The characteristic and specific features of administrative responsibility include, first of all, the fact that its basis is a special type of offense - an administrative offense. Administrative responsibility is expressed in the application of certain types of administrative penalties, specific in content and different from the measures of criminal punishment, disciplinary influence and property liability ${ }^{3}$.

Administrative liability for infringement of intellectual property law is characterized by a number of specific features (related to the basis of its origin, the nature of its measures of action and the procedure of application), which allow it to be separated from other types of liability. First of all, the

3 Остапенко Л.О. Адміністративна відповідальність за правопорушення, вчинені в сфері охорони праці : монографія. Львів : Растр-7, 2016. 223 с. 
most important feature of administrative responsibility is that in most cases it is used in extrajudicial procedural forms.

Public administration is the responsibility of public authorities. Due to the specificity of the intellectual property objects, the legislator has restricted the range of persons authorized to hear such cases. Those charged with the misuse of intellectual property objects are subject to the administrative penalties provided for in Art. 24 Coupe.

The main source of norms that establish administrative liability for the illegal use of intellectual property is the Code of Administrative Offenses (CUAP), which lists administrative offenses, administrative penalties and authorities that are authorized to apply them. The rules on administrative liability for infringement of intellectual property rights are contained in Chapters 6, 9, 12 of the Code of Administrative Offenses. Such administrative offenses can be attributed to Art. 51-2 (Chapter 6) Art. 107-1 (Chapter 9) and Art. Art. 156-3 (as regards intellectual property), 164-3, 164-6, 164-7, 164-9, 164-13 (Chapter 12). In parallel with the Administrative Code, the Customs Code of Ukraine is in force, which contains rules that establish administrative liability for violation of customs rules. Special legal legislation in the field of intellectual property is also part of the legal acts containing administrative liability issues, but the rules of this legislation do not impose administrative sanctions for the illegal use of intellectual property objects.

Thus, administrative responsibility for infringement of intellectual property law is the responsibility for a particular type of offense, and therefore all the features and principles of a coherent institution of administrative responsibility are inherent in it.

\section{Administrative offense in the field of intellectual property as a basis of administrative responsibility}

The basis for the application of administrative responsibility for infringement of intellectual property rights is a homogeneous group of administrative offenses - administrative offenses in the field of intellectual property. The quality of interpretation of the concept of an administrative offense depends on the resolution of specific issues of administrative law, such as grounds of administrative responsibility, determination of the range of its subjects, qualification of administrative offenses and the application of administrative penalties for their commission. Each administrative offense is committed by a specific person or group of persons at a specific place and time and is contrary to the applicable legal norm, characterized by clearly defined features.

Article 9 of the Code of Administrative Offenses (CUAPA) defines an administrative offense as unlawful, guilty (intentional or negligent) act or 
omission that encroaches on public order, property, rights and freedoms of citizens, the established administrative procedure and for which the law provides for administrative liability ${ }^{4}$. This article defines the general concept of "administrative offense", reveals its material content, legal nature and social nature, analyzing which can formulate the main features of administrative offense, in particular, and offenses in the field of intellectual property. Objective signs of an administrative offense are its social harm, wrongfulness and punishment, and subjective - guilt and subjectivity. Only in the presence of all these signs can one speak of qualifying an individual's act as an administrative offense and resolving the issue of bringing him to administrative responsibility.

The first sign of administrative offenses in the field of intellectual property is their social harmfulness, which is the violation of intellectual property rights and causing harm (material and intangible) or creating a threat to the subjects of those social relations that have arisen from the use of the results of intellectual activity are protected by administrative liability law. Public harmfulness of an administrative offense means that it causes harm to certain social relations, which are protected by legal norms: state and public order, property, rights and freedoms of citizens, established management order $^{5}$. This damage can be both material and other (moral, organizational, etc.). The act or omission of the entity causes or threatens to cause harm (material, moral, organizational or other) to the objects of administrative and legal protection, in this case an encroachment on intellectual property rights, such as copyright or trademark rights. Public harmfulness in these cases is an objective property of such offenses and a real violation of the intellectual property rights relationship, constituting "the destruction of the social wrongdoing in the object - relations of the right to intellectual property objects" $"$.

An administrative offense should be considered a socially harmful act with a degree of danger less than that found in the criminal offense. As for the assessment of the public harmfulness of administrative violations of intellectual property rights, it occurs at two levels: legislative (to date, the legislator has already placed most of the composition of these offenses in the Code of Administrative Offenses (Art. 51-2, 107-1, 156-3 (in relation to intellectual property objects), 164-3, 164-6, 164-7, 164-8, 164-9, 164-13) and

\footnotetext{
${ }^{4}$ Кодекс України про адміністративні правопорушення : Закон України від 7 грудня 1984 p. № 8073-X. URL.: http://www.zakon.rada.gov.ua/go/80731-10.

${ }^{5}$ Олішевський О.В. Соціально шкідливі наслідки сприйняття інформації, що містить пропаганду культу насильства і жорстокості. Форум права. 2016. № 2. С. 135-139.

6 Селіваненко В.В. Форми порушення та захист прав суспільства на об'єкти інтелектуальної власності у сфері охорони здоров'я. Часопис Київського університету права. 2013. № 3. С. 223-228.
} 
law enforcement (when the authorities assess its degree in a particular in case of infringement of intellectual property rights).

Social harmfulness belongs to evaluation concepts, and the criterion of its degree is the objective and subjective features of the composition of the administrative offense in the field of intellectual property: a specific object of intellectual property (the result of a person's literary and artistic activity, the result of his scientific and technical activity or the result individualization of goods (services) and their manufacturers), consequences, method of committing an administrative offense, guilt, motive and purpose. The damage caused by the infringement in the field of intellectual property finds its assessment in the sanction of the legal norm.

Administrative offenses in the field of intellectual property that directly cause damage are manifested in the real, material result (they are called offenses with material composition). These include, in particular, the display and distribution of films without a state certificate for the right to distribute and display films (Art. 164-4 of the Code of Administrative Offenses), the illicit distribution of copies of audiovisual works, phonograms, videograms, computer programs and databases (Art. 164-9 KUPAP).

Administrative offenses, which involve only danger or the possibility of causing harm and encroach on the legal form, are formal. Such are, for example, infringement of intellectual property rights (Art. 51-2 of the Code of Administrative Offenses), violation of the legislation governing the production, export, import of wild game for laser reading systems, export, import of equipment or raw materials for their production (Art. 164-13 CUP).

The nature of the act (repetition or gross misconduct) is also affected by the extent of the public nuisance of the offense, which accordingly leads to increased administrative responsibility. Therefore, the importance of social harmfulness as a material feature of an administrative offense in the field of intellectual property is that it is the main objective criterion for recognition of an act as administratively illegal, allows to classify a specific administrative offense, defines the boundary between it and other offenses (in particular, a crime). one of the general principles of individualization of administrative responsibility and punishment, and also determines the existence of grounds for exemption from administrative responsibility. awareness.

The legal form of expression of social harmfulness of an administrative offense in the field of intellectual property is its illegality, which indicates the illegality of such acts and their prohibition in the legislation on administrative responsibility. Unlawfulness is an intrinsic property of any administrative misconduct, which consolidates both the negative assessment of a certain act by the legislator, as a representative of the state, and the actual fact of leveling the 
legal order that determines the relevant attitude to the person-delinquent ${ }^{7}$. The sign of the unlawfulness of an administrative offense stems from the fact that it is prohibited by law as causing damage or threatening to cause such harm.

Unlawfulness, as a sign of an administrative offense in the field of intellectual property, provides for a direct indication of this in the law, that is, it excludes the possibility of administrative liability for actions not provided for by the legislation on administrative offenses. An administrative offense recognizes only such unlawful act for which the law provides for a special type of state coercion - administrative responsibility. Unlawfulness of an administrative offense is a violation of mandatory rules established by the state. An administrative offense can be manifested in both unlawful action and unlawful inaction.

Administrative unlawfulness is closely linked to public harm and is an objective manifestation of the real harmfulness of actions for public relations in the field of intellectual property and its legislative evaluation. In addition, administrative unlawfulness is a legal feature of public harm, and its degree determines the objective limits of unlawfulness, beyond which the question of criminalization of this act already arises ${ }^{8}$. Allocation of administrative unlawfulness as a mandatory sign of an administrative offense is a concrete expression of the principle of legality in administrative law, since administrative liability is subject only to the person who committed a socially harmful act (the subject of misconduct), ie an act of specific, conscious and volitional behavior in the form of inaction, which is contrary to administrative law. Due to the presence of such a feature of administrative offenses in the field of intellectual property as unlawfulness, among all possible human acts in the specified area, those offenses which are recognized administratively punished and which are the subject of legal regulation of administrative law are distinguished. In addition, the function of administrative wrongdoing lies in its importance for distinguishing administrative offenses in the field of intellectual property from related administrative offenses.

Another obligatory feature of administrative offenses in the field of intellectual property, which is detected at the time of the offense and reflects its internal psychological content, is the presence of guilt. Thus, an administrative offense is not only a socially harmful, unlawful, but also a guilty act, that is, a result of the offender's will and mind. Guilt implies the presence of a person's own mental

${ }^{7}$ Калєніченко Л.І. Об'єктивно протиправне діяння як фактична підстава юридичної відповідальності (аналіз галузевого законодавства). Вісник Харківського національного університету внутрішніх справ. 2016. Вип. 4. С. 19-28.

${ }^{8}$ Письменський С.О. Реалізація кримінально-правової політики шляхом криміналізації та декриміналізації: аналіз поточних законодавчих ініціатив. Часопис Київського університету права. 2015. № 1. С. 230-234. 
attitude to the relevant act and its consequences ${ }^{9}$. Guilt forms are of great legal importance. Acting deliberately, the offender is aware of the unlawful nature of his act, anticipates and desires (direct intent) or knowingly permits (indirect intent) the occurrence of harmful consequences. An administrative offense may also be committed by negligence. Negligence is manifested in the form of overconfidence or negligence.

Administrative offense in the field of intellectual property is the unity of objective and subjective: act and mental (conscious and volitional) attitude to it. As an act cannot be disclosed out of touch with a person's mental attitude to it, so does the meaning of a mental attitude not be determined out of touch with the nature of the act: the result of the intellectual creative activity that the person is afflicting, the way of the assault, the consequences, and others. its objective features. Wine largely determines the nature of the act and the degree of its severity and is an important criterion for recognizing it as an administrative offense. Without fault, there is no wrongdoing, and therefore there can be no administrative influence for one or another act against intellectual property. Thus, the presence of the offender's guilt in one form or another is an important and necessary sign of an administrative offense, which facilitates the qualification and clarification of qualifications, determines the objectivity of the approach in determining the degree and type of aggravation charged to the perpetrator.

An important feature of an administrative offense in the field of intellectual property is its administrative punishment, which is understood to mean the threat of punishment for a given offense contained in administrative sanctions in due cases. A specific act (act or omission) can be recognized as an administrative offense only if its law provides for administrative liability ${ }^{10}$.

It is an outward sign of misconduct - punishment. Punishment, by its very nature, stems from public harm and administrative wrongdoing: it therefore becomes administratively punishable, since it is socially harmful and envisaged by administrative law as an offense. This feature allows to distinguish the offense from other unlawful acts, the implementation of which does not entail the use of administrative penalties.

In addition, it should be noted that the character of administrative punishment is closely related to the legal consequences of applying administrative liability measures.

9 Венгер Ю.В. Вина як суб'єктивна підстава адміністративної відповідальності юридичної особи за вчинене правопорушення у сфері стандартизації. Науковий вісник Міжнародного гуманітарного університету. Серія : Юриспрудениія. 2015. Вип. 13 (1). C. $85-87$.

${ }^{10}$ Чишко К.О. Адміністративно-правова кваліфікація та кваліфікація адміністративного правопорушення (проступку): поняття, ознаки, передумови. Вісник Харківського національного університету внутрішніх справ. 2015. Вип. 3. С. 150-158. 
Without any administrative sanction, it is impossible to combat any offense $^{11}$. However, this does not mean that the penalty provided for in the sanction must necessarily be applied to the person who committed the act formulated in the disposition of a particular article. A person recognized as an offender may be released from administrative liability. In some cases, the presence of all signs of an administrative offense in a person's act does not mean that the act automatically entails the administrative liability provided for by the Code of Administrative Offenses. For example, according to Art. 18 of the Code of Administrative Offenses, an act that contains all the features of an administrative offense is not such if it was committed in an emergency. With regard to intellectual property, an urgent need may arise in the following cases: in the case of using the patented claims without the consent of the patentee to create a medicinal product necessary for the preservation of human life and health ${ }^{12}$. However, the urgency does not allow for the use of procedures for obtaining a patent owner's license or a compulsory license.

And the last sign of this type of administrative offense is their subjectivity. Administrative offenses in the field of intellectual property are acts committed by the subject of the offense, since not every person who commits a publicly harmful administrative-unlawful act is subject to administrative responsibility ${ }^{13}$. She should be aware of and manage her own actions, reach a certain age, and so on. The notion of subjectiveness of administrative offenses in the field of intellectual property is important in the context of the development of the theory of administrative misconduct, the improvement of administrative and jurisdictional activities for their prevention, as well as ensuring the coherence of administrative enforcement measures with the nature of the respective offenses.

The peculiarity of the administrative legislation on intellectual property lies in the fact that its rules provide for both administrative responsibility for committing illegal actions on the objects of intellectual property and protection of the property interests of the subjects of intellectual property rights whose rights are violated by such actions. Due to the fact that the legal relations with respect to certain intellectual property objects are regulated by

${ }^{11}$ Колпаков В.К. Фактичні ознаки та юридичний склад адміністративного проступку: поняття та розмежування. Вісник Запорізького національного університету. Юридичні науки. 2016. № 3. С. 160-170.

12 Микитин B.I. Окремі аспекти наслідків порушення прав інтелектуальної власності. Науковий вісник Херсонського державного університету. Серія : Юридичні науки. 2016. Вип. 2(1). С. 79-83.

13 Фролов О. С., Васильєв І. В. Зміст та обсяг концепту “суб’єкт адміністративного правопорушення". Держава $і$ право. Юридичні $i$ політичні науки. 2014. Вип. 66. C. 105-117. 
special laws, the administrative law should be guided by the provisions of that special law, which provides for the protection of the personal non-property and property rights of authors and their successors (rights related the creation and use of works of science, literature or art), as well as the rights of performers, producers of phonograms and videograms, and of broadcasting organizations and inventors' rights. Thus, for the qualification of an administrative offense in the field of intellectual property, it is necessary to have clearly expressed its features.

Thus, an administrative offense in the field of intellectual property can be defined as envisaged by the legislation on administrative responsibility socially harmful, unlawful, guilty act (act or omission) committed by the subject of such unlawful acts that encroach on the set of property and personal non-property rights to intellectual property results. creative activity of a person (results of literary and artistic activity (objects of copyright (literary and artistic works, computer programs, databases $\mathrm{x}$ ) and related rights (performance, phonograms, videograms and programs (broadcast))), scientific and technical creativity (invention, utility model, industrial design, scientific discovery, layout of integrated circuits, innovative offer, plant variety, animal breed and commercial secrecy) and the individualisation of goods (services) and their manufacturers (trade name, trademark and geographical indication). Committing a person of an administrative violation in the field of intellectual property containing the composition of an administrative violation is a ground for bringing him to administrative responsibility and applying to it appropriate administrative penalties, depending on the type of offense in relation to specific intellectual property objects, responsibility for violation of rights for which are established by law.

\section{Legal structure of administrative offenses in the field of intellectual property}

For the proper qualification of administrative offenses in the field of intellectual property, it is essential to characterize the characteristics of their composition. Thus, the composition of an administrative offense is the set of objective and subjective features established by the legislation on administrative liability that determine a specific socially harmful act by an administrative offense.

To all structures of administrative offenses in the field of intellectual property (Art. 51-2, 107-1, 156-3 (as regards the objects of intellectual property), 164-3, 164-6, 164-7, 164-8, 164-9, 164-13), as well as other administrative offenses, there are such elements as objective signs (they are the totality of the generic object and the objective side of the compositions of these administrative offenses) and subjective signs (a set of relevant entities 
and a subjective side), which in their unity form the administrative offenses of tollgates group.

It is advisable to begin characterizing the objective features of the composition of administrative offenses in the field of intellectual property with the disclosure of their ancestral object - what the offender is afflicted with and why it causes or may cause harm. It is the object that allows to determine the social essence of an administrative offense, to find out its socially harmful consequences and the mechanism of causing harm, promotes the correct qualification of the act, as well as to differentiate it from related socially harmful acts. In our view, warehouses of administrative offenses have their own single generic object - public relations of intellectual property, which are protected by the law on administrative responsibility.

Thus, in our opinion, there are sufficient legal grounds to separate intellectual property relations into a separate independent group of public relations. But the generic object of administrative offenses in the field of intellectual property is not only their entirety, but only part of it, which is protected by the Code of Administrative Offenses, while acquiring the status of intellectual property law enforcement relations.

Thus, the generic object of the group of administrative offenses under investigation is the law enforcement relations of intellectual property, which feature a number of characteristic features. First, they are the subject of intellectual property - the results of intellectual creative activity. Secondly, they are a continuation of the intellectual property regulatory legal relationship and arise as a result of administrative offenses of the relevant Special Part of the Code of Administrative Offenses, exercising the right of an intellectual property subject to an administrative offense, to be compulsorily and indirectly protected. Thirdly, they are aimed at bringing the offender to administrative responsibility for the committed. Thus, the generic object of the composition of administrative offenses defined in the above articles is the public relations of intellectual property, which are protected by the law on administrative responsibility.

The objective side of administrative offenses under Art. Art. 51-2, 107-1, 156-3 (in the part concerning intellectual property), 164-3, 164-6, 164-7, 164-8, 164-9 and 164-13 of the Administrative Code, represents a set of features that characterize IPR infringement as outward conduct. The objective side is understood by scholars as a system of features prescribed by the rule of law, which characterize the outside of an administrative offense. The attributes of its objective side include acts in the form of actions or omissions, its socially harmful effects and the causal link between the act and its consequences.

In the Code of Administrative Offenses unlawful acts in the field of intellectual property are defined as "infringement of rights" (art. 51-2), "violation 
of statutory requirements" (art. 156-3), "unfair competition" (art. 164-3), "infringement conditions "(vv. 164-7),“ illegal distribution "(vv. 164-9)," violation of the law "(vv. 164-13). An analysis of the dispositions of these articles convinces that administrative offenses can be committed through action, but since the wording "other deliberate violation" (v. 51-2) contains an inexhaustible list of actions, the question arises as to the possibility of committing these offenses by inaction ${ }^{14}$. In the dispositions of the articles under study, the domestic legislator, using the notion of "illegal use" as well as illegal "demonstration", "dissemination", etc., reveals their content without giving a complete or even partial list of illegal acts that should be considered unlawful.

It should also be borne in mind that each type of intellectual property is subject to the law by the legislator. Typical infringements of copyright and related rights are: the commission by any person of actions that violate the personal non-proprietary rights of copyright subjects and (or) related rights; piracy in the field of copyright and (or) related rights; plagiarism; importation into the customs territory of Ukraine without the permission of copyright holders and (or) related rights, copies of works (including computer programs and databases), phonograms, videograms, broadcast programs; committing acts that threaten copyright and / or related rights; any actions deliberately aimed at circumventing the technical means of copyright protection and (or) related rights, including the manufacture, distribution, importation for the purpose of distribution and use of the means for such circumvention; falsifying, altering or deleting information, including in electronic form, about rights management without the permission of the copyright entities and / or related rights or the person exercising such management; distribution, importation into the customs territory of Ukraine for the purpose of distribution, public notification of copyright and (or) related rights, from which, without permission of copyright and (or) related rights, information on management of rights has been removed or altered, in particular in in electronic form ${ }^{15}$.

Infringement of intellectual property rights on the results of scientific and technical creativity is considered, for example, disclosure without the consent of the author or the applicant of the essence of the invention, utility model or industrial design before the official publication of information about them ${ }^{16}$.

${ }^{14}$ Самбор М.А., Самбор А.М. Інші та подібні дії як елемент складу адміністративного правопорушення та його вплив на кваліфікацію діяння як адміністративного проступку. Науковий вісник Дніпропетровського державного університету внутрішніх справ. 2014. № 3. С. $143-160$.

${ }^{15}$ Криволапов Б.М., Тесленко Н.В. Порушення авторського права як актуальна проблема для України. Актуальні проблеми міжнародних відносин. 2015. Вип. 124 (1). С. 85-93.

16 Бондаренко О.О. Основні напрями удосконалення національного законодавства у сфері охорони промислових зразків в Україні. Науковий вісник Міжнародного гуманітарного університету. Серія : Юриспрудениія. 2015. Вип. 15(2). С. 4-7. 
The unauthorized use of a trade mark is recognized as the unauthorized manufacture, use, importation, offering for sale, sale, other introduction into civil circulation or storage for the purpose of the trade mark, or the determination of similar things up to the mixing of homogeneous goods. It shall be considered an offense to use, without the consent of the owner, both the said images themselves and similar images if the latter are used for goods which are homogeneous with those for which the image is intended ${ }^{17}$. According to the construction of the objective side of intellectual property offenses, administrative responsibility for these offenses also arises in the case of any other intentional infringements of intellectual property rights ${ }^{18}$.

Subjective features of administrative offenses in the field of intellectual property are the unity of the subject and the subjective side, and their specificity is determined by the peculiarities of the subject of these offenses, elements of which are various objects of intellectual property that are actively used in business activities of enterprises and organizations.

Another subjective feature of the composition of administrative offenses in the field of intellectual property is their subjective side, which is defined as the internal side of administrative offenses, which covers the mental attitude of a person to a socially harmful act, and its consequences ${ }^{19}$. The subjective party, in turn, has mandatory and optional features. A mandatory feature of the subjective side of administrative offenses is wine. Consequently, the perpetrator of the infringement of intellectual property rights was aware that he was illegally using the objects of intellectual property rights, attributing authorship to them or otherwise violating the intellectual property rights, foreseeing the possibility of causing material damage, and wished or tolerated such consequences ${ }^{20}$.

Optional features of the subjective side of administrative offenses in the field of intellectual property are the motive and purpose of the perpetrator. That is, the perpetrator, in violation of intellectual property rights, was aware that he was illegally using the objects of intellectual property rights, assigning

17 Коваленко Т.В. Торговельна марка та авторське право. Теорія $i$ практика інтелектуальної власності. 2016. № 4. С. 51-58.

18 Барладян О.С. Особливості притягнення до адміністративної відповідальності за правопорушення, що посягають на об'єкти інтелектуальної власності. Науковий вісник Ужсгородського національного університету. Серія : Право. 2016. Вип. 36. С. 11-15.

${ }^{19}$ Мельничук Н.Ю., Сьома М. Еволюція категорій правопорушення та адміністративна відповідальність. Наукові записки Львівського університету бізнесу та права. 2014. № 12. C. $60-64$.

20 Світличний О.П. До питання встановлення адміністративної та кримінальної відповідальності юридичних осіб за порушення прав інтелектуальної власності. Науковий вісник Національного університету біоресурсів і природокористування Украӥни. Серія : Право. 2014. Вип. 197(1). С. 163-169. 
authorship to such objects or otherwise intentionally violating the rights to intellectual property objects, provided for the possibility of causing material damage and wanted or wanted allowed for these consequences.

That is, obligatory signs of administrative offenses in the field of intellectual property are their social harmfulness (it is manifested in causing harm to public relations in the sphere of intellectual property or creating a threat of its infliction), administrative illegality (illegality of unlawful acts in the field of intellectual property, liability), punishment (threat of administrative influence, determined by the law on administrative liability for koyennya such administrative offense) and subjectivity (wrongful act committed administrative offense subject to intellectual property).

Thus, the legal structures of intellectual property offenses form a unity of their objective (subject and objective side) and subjective (subject and subjective) features. The only generic object of these administrative offenses is the group of public intellectual property relations, which are protected by the law on administrative liability. The objective side of administrative offenses in the field of intellectual property is the set of ways of infringing intellectual property rights. The subjective signs of the administrative offenses of this group are represented by their subject, and the subjective side is characterized by the fact that they are committed only intentionally.

\section{CONCLUSIONS}

The realization of administrative responsibility for infringements in the field of intellectual property is carried out in the form of enforcement, that is, the own activity of authorized subjects, which consists in the application of administrative legal norms to specific facts of committing legally significant actions. In this case, enforcement is the implementation by the authorized state bodies and officials of the actions envisaged by law to bring the perpetrators of the offenses in the field of intellectual property to administrative responsibility. Pursuant to applicable law, administrative liability is the sole prerogative of state bodies and, in some cases, local selfgovernment bodies, which makes it necessary to provide all procedures related to these activities with appropriate procedural form.

Therefore, based on the foregoing features of this proceeding, the following definition of the definition of "intellectual property lawsuits" can be given: intellectual property lawsuits are one type of administrative jurisdictional representation a series of sequential actions of the competent authorities, provided by the current legislation, on the detection of administrative offenses in the field of intellectual property and bringing those responsible to administrative responsibility in the process of administrative investigation, consideration and decision on the case, reconsideration and enforcement of the decision (decision) imposing administrative penalties. 
Individuals are brought to administrative responsibility in the form of proceedings in cases of administrative offenses, and legal entities - in the procedural forms established by various regulatory legal acts. Administrative cases in the field of intellectual property infringement should be understood as one of the types of administrative jurisdictional proceedings, which is a series of sequential actions of the competent authorities, provided by the current legislation, to identify administrative offenses in the field of intellectual property and to bring administrative proceedings. investigate, review and decide on the case, review and enforce state (decision) on imposition of administrative penalties.

The following stages of administrative offenses are traditionally distinguished: administrative infringement proceedings (it consists of three stages: official registration by the authorized body (official) of factual data on infringement of intellectual property rights, official activity of the authorized bodies for finding out drafting a protocol); consideration of an administrative offense case and decision-making process (four stages should be distinguished at this stage: preparation for the case; substantive examination; decisionmaking and execution of the case; announcement of the decision); appeal and appeal against the decision on the administrative offense case; enforcement of the decision, enforcement of administrative penalties.

\section{SUMMARY}

The basis for the application of administrative responsibility for infringement of intellectual property rights is a homogeneous group of administrative offenses - administrative offenses in the field of intellectual property. Only in the presence of all signs can one speak of qualifying an individual's act as an administrative offense and resolving the issue of bringing him to administrative responsibility. Based on the above features, an administrative offense in the field of intellectual property can be defined as envisaged by the legislation on administrative liability of socially harmful, unlawful, guilty act (act or omission) committed by the subjects of such unlawful acts that affect the totality of property and personal property. results of conscious intellectual creative activity of a person (results of literary and artistic activity (objects of copyright (literary and artistic works, computer software program databases) and related rights (performance, phonograms, videograms and programs (broadcast))), scientific and technical creativity (invention, utility model, industrial design, scientific discovery, integrated circuit layout, innovative offer, plant variety, breed) animals and trade secrets) and the individualisation of goods (services) and their manufacturers (trade name, trade mark (sign for goods and services) and geographical indication)). 
For the proper qualification of administrative offenses in the field of intellectual property, it is essential to characterize the features of their warehouses. Administrative responsibility for offenses in the field of intellectual property is carried out in the form of enforcement, which consists in the implementation by the authorized state bodies and officials of the actions envisaged by law to bring persons who have committed offenses in this area to administrative responsibility.

\section{REFERENCES}

1. Миколенко О.І., Стукаленко В.А., Стукаленко О.В. Адміністративна відповідальність посадових осіб за порушення виборчого законодавства : навч. посіб. Кіровоград : Полімед-Сервіс, 2014. 170 с.

2. Олійник В.І. Адміністративна відповідальність за правопорушення в галузі рослинного світу України : монографія. Харків : НікаНова, 2015. $221 \mathrm{c}$.

3. Остапенко Л.О. Адміністративна відповідальність за правопорушення, вчинені в сфері охорони праці : монографія. Львів : Растр-7, 2016. 223 с.

4. Кодекс України про адміністративні правопорушення : Закон України від 7 грудня 1984 p. № 8073-X. URL: http://www.zakon.rada.gov.ua/ go/80731-10.

5. Олішевський О.В. Соціально шкідливі наслідки сприйняття інформації, що містить пропаганду культу насильства і жорстокості. Форум права. 2016. № 2. С. 135-139.

6. Селіваненко В.В. Форми порушення та захист прав суспільства на об'єкти інтелектуальної власності у сфері охорони здоров'я. Часопис Київського університету права. 2013. № 3. С. 223-228.

7. Калєніченко Л.І. Об'єктивно протиправне діяння як фактична підстава юридичної відповідальності (аналіз галузевого законодавства). Вісник Харківського начіонального університету внутрішніх справ. 2016. Вип. 4. С. 19-28.

8. Письменський Є.О. Реалізація кримінально-правової політики шляхом криміналізації та декриміналізації: аналіз поточних законодавчих ініціатив. Часопис Київського університету права. 2015. № 1. C. 230-234.

9. Венгер Ю.В. Вина як суб'єктивна підстава адміністративної відповідальності юридичної особи за вчинене правопорушення у сфері стандартизації. Науковий вісник Міжнародного гуманітарного університету. Серія : Юриспрудениія. 2015. Вип. 13(1). С. 85-87.

10. Чишко К.О. Адміністративно-правова кваліфікація та кваліфікація адміністративного правопорушення (проступку): поняття, ознаки, передумови. Вісник Харківського національного університету внутрішніх справ. 2015. Вип. 3. С. 150-158. 
11. Колпаков В.К. Фактичні ознаки та юридичний склад адміністративного проступку: поняття та розмежування. Вісник Запорізького національного університету. Юридичні науки. 2016. № 3. С. 160-170.

12. Микитин B.I. Окремі аспекти наслідків порушення прав інтелектуальної власності. Науковий вісник Херсонського державного університету. Серія : Юридичні науки. 2016. Вип. 2(1). С. 79-83.

13. Фролов О.С., Васильєв І. В. Зміст та обсяг концепту “суб'єкт адміністративного правопорушення". Держава $i$ право. Юридичні $i$ політичні науки. 2014. Вип. 66. С. 105-117.

14. Самбор М.А., Самбор А.М. Інші та подібні дії як елемент складу адміністративного правопорушення та його вплив на кваліфікацію діяння як адміністративного проступку. Науковий вісник Дніпропетровського державного університету внутрішніх справ. 2014. № 3. С. 143-160.

15. Криволапов Б.М., Тесленко Н.В. Порушення авторського права як актуальна проблема для України. Актуальні проблеми міжнародних відносин. 2015. Вип. 124(1). С. 85-93.

16. Бондаренко О.О. Основні напрями удосконалення національного законодавства у сфері охорони промислових зразків в Україні. Науковий вісник Міжнародного гуманітарного університету. Серія : Юриспруденція. 2015. Вип. 15(2). С. 4-7.

17. Коваленко Т.В. Торговельна марка та авторське право. Теорія $i$ практика інтелектуальної власності. 2016. № 4. С. 51-58.

18. Барладян О.С. Особливості притягнення до адміністративної відповідальності за правопорушення, що посягають на об'єкти інтелектуальної власності. Науковий вісник Ужгородського національного університету. Серія : Право. 2016. Вип. 36(2). С. 11-15.

19. Мельничук Н.Ю., Сьома М. Еволюція категорій правопорушення та адміністративна відповідальність. Наукові записки Львівського університету бізнесу та права. 2014. № 12. С. 60-64.

20. Світличний О.П. До питання встановлення адміністративної та кримінальної відповідальності юридичних осіб за порушення прав інтелектуальної власності. Науковий вісник Національного університету біоресурсів $і$ природокористування Украӥни. Серія : Право. 2014. Вип. 197(1). С. 163-169.

Information about the author: Todoshak O. V.,

$\mathrm{PhD}$ in Law, Associated Professor at the Department of Administrative and Financial Law, National University "Odessa Law Academy" 2, Academychna str., Odessa, 65009, Ukraine 